\title{
Minimum and Maximum Protection Under International Copyright Treaties
}

\author{
Jane C. Ginsburg ${ }^{*}$
}

Introduction 1

I. The Two Pillars of International Copyright Treaties ...................................

A. Meanings of "Minima" and "Maxima"..........................................

B. Policy Underlying Berne Maxima and Its Preclusive Effect.......7

II. Berne/TRIPS/WCT Maxima Applied: The Case of the DSM Directive

Article 15 Press Publishers' Right ....................................................8

A. Why Create a Press Publishers' Right? ......................................

B. Does DSM Directive Article 15 Bestow Copyright Protection on

Berne-Excluded Subject Matter? ..............................................10

C. May the EU Protect Berne-Adjacent Subject Matter Through Sui Generis Systems?.

III. Even Were a Sui Generis Right in Berne-Excluded Subject Matter

Permissible, Must Exceptions To that Right Be Interpreted Co-

Extensively with the Berne Article 10(1) Quotation Right?

IV. Conclusion 18

\section{INTRODUCTION}

This Comment addresses minimum and maximum substantive international protections set out in the Berne Convention and subsequent multilateral copyright accords. While much scholarship has addressed Berne minima, ${ }^{1}$ the maxima have

* Morton L. Janklow Professor of Literary \& Artistic Property Law, Columbia Law School. Many thanks for comments and suggestions to Lionel Bently, Annette Kur, and James Parrish, and for excellent research assistance to Eric Speckhard, Columbia Law School, Class of 2020.

1. See, e.g., SAM RICKETSON \& JANE C. GINSBURG, INTERNATIONAL COPYRIGHT AND NeIghbouring Rights: The BERnE CONVENTION AND BEyOnd ch. 8-12, at 399-754 (2d ed. 2006); SilKe VON LEWINSKi, INTERNATIONAL COPYRIGHT LAW AND POLICY $\mathbf{q}$ 5.94-5.147 (2008); PAUL Goldstein \& Bernt Hugenholz, International Copyright: Principles, Law, Practice ch. 9, at 303-56 (3d ed. 2013); Paul Edward Gellar, International Copyright: The Introduction, in 1 INTERNATIONAL COPYRIGHT LAW AND PRACTICE INT-1, § 5, at INT-139 to -188 (Lionel Bently ed., 2018), https://perma.cc/4FAX-QNU6.

(C) 2020 Ginsburg. This is an open access article distributed under the terms of the Creative Commons Attribution-NonCommercial-NoDerivatives License, which permits noncommercial use, distribution, and reproduction, provided the original author and source are credited, and the article is not changed. 
generally received less attention. ${ }^{2}$ It first discusses the general structure of the Berne Convention, ${ }^{3}$ TRIPS, ${ }^{4}$ and the $\mathrm{WCT}^{5}$ regarding these contours, and then analyzes their application to the recent "press publishers' right" promulgated in the $2019 \mathrm{EU}$ Digital Single Market Directive. ${ }^{6}$

\section{THE TWO PILLARS OF INTERNATIONAL COPYRIGHT TREATIES}

The Berne Convention and subsequent multilateral copyright accords rest on two pillars: national treatment and supranational substantive obligations. National treatment is a rule of non-discrimination: A member state may not accord foreign authors less protection than it grants its own. But a second principle buttresses the first: Whatever level of protection national law provides, a treaty member state must grant foreign authors protection commensurate with the treaties' substantive standards. Most often that obligation means that member states whose domestic laws fall below the treaty minima must accord more protection to foreign authors than they do to their own. Berne's drafters anticipated that the political precariousness of such an outcome would result in a general raising of the level of domestic protection as well. ${ }^{7}$ In the case of Berne maxima, in theory, a member state could deny foreign Berne works protections that it extends to local authors, if that coverage concerns subject matter the treaties exclude or rights that a mandatory exception mitigates. But, as the drafters also may have anticipated, most national laws are likely to incorporate Berne's mandatory exclusions and exceptions, so that a downward discrepancy between local law and Berne norms seems improbable. Or did, until the

2. There are notable exceptions. See, e.g., Annette Kur \& Henning Grosse Ruse-Khan, Enough Is Enough-The Notion of Binding Ceilings in International Intellectual Property Protection, in Intellectual Property Rights in a Fair World Trade System: Proposals For Reform of TRIPS 359 (Annette Kur \& Marianne Levin eds., 2011) [hereinafter Kur \& Ruse-Khan, Enough Is Enough, INT'L PROP. RTS.]; Annette Kur \& Henning Grosse Ruse-Khan, Enough Is Enough - The Notion of Binding Ceilings in International Intellectual Property Protection (Max Planck Inst. for Intell. Prop., Competition \& Tax Law Research Paper Series, Paper No. 09-01, 2008), https://perma.cc/GE6G-53LM [hereinafter Kur \& Ruse-Khan, Enough Is Enough, Max Planck Inst.]; TANYA APLIN \& LIONEL BENTLY, GLOBAL MANDATORY FAIR USE: THE NATURE AND SCOPE OF THE Right TO QUOTE COPYRIGHT WORKS (2020) (a monumental study of the Berne Article 10 quotation right). See also Susy Frankel, Challenging TRIPS-Plus Agreements: The Potential Utility of Non-Violation Disputes, 12 J. INT'L ECON. L. 1023, 1030, $1031 \mathrm{n} .31$ (2009) (acknowledging that TRIPS allows member states to legislate TRIPS-plus levels of protection, but suggesting that maxima may be implicit in the structure and purpose of TRIPS, as "higher levels of protection ought to have limits consistent with the wording of the TRIPS Agreement, in light of its object and purpose, its structure and the benefits that can be expected from it"; but expressing skepticism about the ability of specific substantive maxima to respond to technological change). The brief discussion of Berne maxima at RICKETSON \& GINSBURG, supra note 1, ๆ 6.110 will be substantially augmented in the forthcoming third edition.

3. Berne Convention for the Protection of Literary and Artistic Works, Sept. 9, 1886, as revised July 24, 1971, and as amended Sept. 28, 1979, S. Treaty Doc. No. 99-27 (1986) [hereinafter Berne].

4. Agreement on Trade-Related Aspects of Intellectual Property Rights, Apr. 15, 1994, 1869 U.N.T.S. 299, 33 I.L.M. 1197 (1994) [hereinafter TRIPS].

5. WIPO Copyright Treaty, Dec. 20, 1996, 36 I.L.M. 65 (1997) [hereinafter WCT].

6. Directive (EU) 2019/790 of the European Parliament and of the Council of 17 April 2019 on Copyright and Related Rights in the Digital Single Market and amending Directives 96/9/EC and 2001/29/EC, art. 15, 2019 O.J. (L 130) [hereinafter DSM Directive].

7. RICKETSON \& GINSBURG, supra note $1, \boldsymbol{9} 6.90$, at 311. 
passage of the Digital Single Market (DSM) Directive's Article 15 on press publishers' rights called that assumption into question.

\section{A. Meanings of "Minima" And "MaXima"}

First, let's consider minima. The Berne Convention contains many mandatory obligations regarding minimum subject matter and rights. These are the provisions denoted by "shall." Regarding protected subject matter, see, for example, Article 2(1): "The expression 'literary and artistic works' shall include every production in the literary, scientific and artistic domain, whatever may be the mode or form of its expression ...." Or Article 2(3): "Translations, adaptations, arrangements of music and other alterations of a literary or artistic work shall be protected as original works without prejudice to the copyright in the original work." ${ }^{8}$ By contrast, some subject matter provisions clearly signal their optional character. For example, Article 2(4): "It shall be a matter for legislation in the countries of the Union to determine the protection to be granted to official texts of a legislative, administrative and legal nature, and to official translations of such texts." The formulation "[i]t shall be a matter for legislation in the countries of the Union" tells us that protection for the object is permitted, not required (nor prohibited). ${ }^{9}$

With respect to minimum rights, the same expressions identify the right or exception as mandatory or left to local legislation. Hence, for example, Article 8 proclaims: "Authors of literary and artistic works protected by this Convention shall enjoy the exclusive right of making and of authorizing the translation of their works throughout the term of protection of their rights in the original works." 10 But Article 11 bis(2) states: "It shall be a matter for legislation in the countries of the Union to determine the conditions under which the rights mentioned in the preceding paragraph [various forms of communication to the public] may be exercised ...."11

Now consider maxima. Berne and subsequent treaties allow member states to create exceptions and limitations to exclusive rights, generally subject to a variety of conditions. With one exception, Berne does not impose any mandatory restrictions

8. For mandatory protected subject matter, see Berne, art. 2(1) ("literary and artistic works"); Berne, art. 2(3) (derivative works [without prejudice to underlying work]); Berne, art. 2(5) (collections of literary and artistic works [without prejudice]); Berne, art. 18 (restoration of copyright in foreign works in public domain in newly acceding member state); TRIPS, art. 10(1) (computer programs protected as literary works under Berne); TRIPS, art. 10(2) (compilations of data if intellectual creations); WCT, art. 4 (computer programs); WCT, art. 5 (compilations of data).

9. For optional protected subject matter, see Berne, art. 2(4) (official texts); Berne, art. 2(7) (applied art); Berne, art. 2bis(1) (political speeches).

10. For mandatory protected rights, see Berne, art. 6bis (moral rights); Berne, art. 7 (duration); Berne, art. 8 (derivative works); Berne, art. 9(1) (reproduction); Berne, arts. 11, 11bis, 11 ter, 14 (public performance and communication to the public); Berne, art. 12 (translation); Berne, art. 16 (border seizure); TRIPS, art. 11 (rental, under certain conditions); WCT, art. 6 (distribution of hardcopies); WCT, art. 7 (rental, under certain conditions); WCT, art. 8 (making available to the public); WCT, arts. 11-12 (technological protection measures and copyright management information).

11. Berne Article 11bis(2) nonetheless constrains the freedom allowed member states: "[B]ut these conditions shall apply only in the countries where they have been prescribed. They shall not in any circumstances be prejudicial to the moral rights of the author, nor to his right to obtain equitable remuneration which, in the absence of agreement, shall be fixed by competent authority." 
on the scope of exclusive rights. ${ }^{12}$ Because these derogations from exclusive rights are optional, they are not maxima. We will return to the one rights restriction that Berne prefaces with "shall" - a rights maximum—after considering maximum subject matter.

TRIPS and the WCT expressly incorporate the "idea/expression dichotomy," that is, the exclusion of ideas, methods, and processes from the subject matter of copyright. ${ }^{13}$ The Berne Convention does not explicitly adopt this rule, though it may be implicit in the overall concept of "literary and artistic works," or through state practice, given that most or all member states are likely, by text and/or by case law, to exclude these elements from the scope of protection. ${ }^{14}$ The Berne Convention goes further than the later accords in also removing facts from protection (though this exclusion may also be implicit in those agreements). Article 2(8) states: "The protection of this Convention shall not apply to news of the day or to miscellaneous facts having the character of mere items of press information." As a result, a member state may not grant copyright protection to the ideas or facts (as opposed to their expression) contained within the works of foreign authors, thus establishing the maximum scope of subject matter protection for foreign authors. Again, the Berne minima and maxima apply only to works of foreign Berne origin, while "[p]rotection in the country of origin is governed by domestic law." 15

Turning back to maximum rights under Berne, the Article 10(1) quotation provision is a "shall" clause, qualified by a variety of conditions, but on its face is a

12. For permissible, but not mandatory exceptions and limitations, see Berne, art. 2bis(2) (press use of public lectures); Berne, art. 9(2) (exceptions to reproduction right, "three-step test"); Berne, art. 10(2) (uses as illustrations for teaching); Berne, art. 10bis(1) (press use of press articles); Berne, art. $10 \mathrm{bis}(2)$ (incidental use in reporting current events); Berne, art. 11bis(3) (ephemeral recordings); TRIPS, art. 13 (implicitly authorizes exceptions and limitations to all exclusive rights, but "confines" them to the three-step test); WCT, art. 10(1) (may provide for exceptions to WCT rights, subject to three-step test); WCT, art. 10(2) (shall confine exceptions or limitations on Berne Convention rights to three-step test). The Marrakesh Treaty to Facilitate Access to Published Works for Persons Who Are Blind, Visually Impaired, or Otherwise Print Disabled, June 27, 2013, 52 I.L.M. 1312 (2013), is an extra-Berne treaty imposing mandatory exceptions, both domestically and internationally, on Berne subject matter. Its consistency with Berne norms is a matter of some controversy. See, e.g., Sam Ricketson \& Jane C. Ginsburg, The Berne Convention: Historical and Institutional Aspects, in INTERNATIONAL Intellectual Property: A Handbook of CONTEMPORARY ReSEARCh 3-36 (Daniel Gervais ed., 2015); ASSOCIATION LITTÉRAIRE ET ARTISTIQUE INTERNATIONALE (ALAI), REPORT OF THE ALAI AD Hoc COMmitTeE on the Proposals To Introduce Mandatory EXCEPTIONS For the Visually IMPAIRED (2010).

13. See TRIPS, art. 9(2) ("Copyright protection shall extend to expressions and not to ideas, procedures, methods of operation or mathematical concepts as such."); WCT, art. 2 ("Copyright protection extends to expressions and not to ideas, procedures, methods of operation or mathematical concepts as such.").

14. On "state practice" and the interpretation of the Berne Convention, see, for example, RICKETSON \& GINSBURG, supra note 1, 9 ๆ 5.21, 5.24, 5.57; JANE C. GINSBURG \& EDOUARD TREPPOZ, INTERNATIONAL COPYRIGHT LAW: U.S. AND E.U. PERSPECTIVES 103-09 (2015).

15. Berne, art. 5(3). Under EU law, however, facts and expression merged with facts are also excluded. See Case C 469/17 Funke Medien NRW GmbH v. Bundesrepublik Deutschland, ECLI:EU:C:2019:623, ๆ 24 (July 29, 2019) (stating that military reports are not "works" because they are "essentially determined by the information which they contain, so that such information and the expression of those reports become indissociable and that those reports are thus entirely characterised by their technical function"). 
direction to member states to permit the making of "quotations from a work which has already been lawfully made available to the public, provided that their making is compatible with fair practice, and their extent does not exceed that justified by the purpose, including quotations from newspaper articles and periodicals in the form of press summaries." This Comment does not explore Article 10(1) in depth, ${ }^{16}$ but examines the premise that it establishes a mandatory quotation "right" within its purview. Absent a mandatory character, Article 10(1) would not be a true "maximum," and any ceiling it imposes would in fact be retractable. ${ }^{17}$

Tanya Aplin and Lionel Bently contend that there are several indications that this provision imposes a mandatory requirement for member states to provide for a quotation exception. ${ }^{18}$ First, the text: The language "shall be permissible" indicates that the quotation provision is obligatory. ${ }^{19}$ That interpretation is bolstered by the contrasting language used in other, optional provisions. With the exception of Article 10(1), Berne allows member states to institute copyright limitations and exceptions but does not impose them. For example, the very next provision of Article 10 specifies that limitations related to certain educational uses "shall be a matter for legislation in the countries of the Union." ${ }^{20}$ Second, the records of the Stockholm Conference of 1967, where the present language of Article 10(1) was adopted, also support the notion that Article 10(1) is mandatory. ${ }^{21}$ The language of Article 10(1) was initially proposed by the 1963 Study Group, which repeatedly referenced the "right of quotation" and the "right to make quotations," again suggesting that the exception is required. ${ }^{22}$ Finally, Aplin and Bently point to existing commentary interpreting Article 10(1) as mandatory. ${ }^{23}$ Amongst these, some commentators have

16. Tanya Aplin and Lionel Bently have extensively undertaken that task. See APLIN \& BENTLY, supra note 2.

17. Mihály Ficsor notes that Article 10(1) is unique in that it establishes a directly applicable limitation/exception in countries where the Berne treaty is self-executing, whereas all other exceptions and limitations in Berne expressly call for national implementation. See MiHÁly Ficsor, Guide To the COPYRIGHT AND RELATED RightS TREATIES ADMINISTERED BY WIPO \& BC-10.3, at 61 (2003) [hereinafter FICSOR, 2003 WIPO GUIDE]. Nonetheless, as discussed below, Ficsor concludes that the Article 10(1) quotation right is not in fact obligatory on member states, at least in principle.

18. Tanya Aplin \& Lionel Bently, Displacing the Dominance of the Three-Step Test: The Role of Global, Mandatory Fair Use 2-5 (Univ. of Cambridge Faculty of L. Research Paper, Paper No. 33/2018), https://perma.cc/H9AL-EEER [hereinafter Aplin \& Bently, Three-Step Test].

19. Id. at 2. It has also been pointed out that, in this respect, the French text is perhaps even clearer. There, Article 10(1) provides, "Sont licite les citations ..." which indicates that quotations are permitted rather than merely permissible. See FICSOR, 2003 WIPO GUIDE, supra note 17, 9 BC-10.2.

20. Berne, art. 10(2). Similarly, Berne, art. 10bis(1) allows member states to "permit the reproduction by the press ... of articles published in newspapers or periodicals on current economic, political or religious topics," provided the source is clearly indicated.

21. Aplin \& Bently, Three-Step Test, supra note 18, at 2-3.

22. 1 WIPO, ReCORDS OF THE INTELleCtuAl PROPERTy CONFERENCE OF STOCKHOLM, JUNE 11 To JuLY 14, 1967, at 116-17 [hereinafter WIPO, STOCKHOLM] (emphases added).

23. Aplin \& Bently, Three-Step Test, supra note 18, at 3-4. For commentators interpreting Article 10 (1) as mandatory, see, for example, GoLDSTEIN \& HUGENHOLTZ, supra note 1, § 11.4.1, at 392 ("Article 10(1) of the Berne Paris Text obligates members to permit quotations ...."); RICKETSON \& GINSBURG, supra note 1, 13.53; Kur \& Ruse-Khan, Enough Is Enough, INTELL. PROP. RTS., supra note 2, at 380; Annette Kur, Of Oceans, Islands, and Inland Water-How Much Room for Exceptions and Limitations 
suggested that the exceptional mandatory status of Article 10(1) reflects its dual operation: It is a limitation that curbs one author's right in order to benefit not only the general public, but also other authors, who in many fields rely upon the ability to quote other works. ${ }^{24}$ This rationale, however, does not explain why permitted exceptions, many of which also further downstream authorship, should not also be mandatory. ${ }^{25}$

Nonetheless, not all commentators agree that Article 10(1) is mandatory; some contend that the provision merely permits rather than requires a quotation right. ${ }^{26}$ Mihály Ficsor, for example, has argued that because Berne expressly provides that member states can enter into agreements providing higher levels of protection, ${ }^{27}$ Article 10(1) is not obligatory, at least in principle. ${ }^{28}$ Ficsor also notes that the practice of member states, specifically the European Union, has been to interpret Article 10(1) as optional. ${ }^{29}$ In particular, the InfoSoc Directive expressly provides that "Member States may provide for exceptions and limitations" as to

quotations for purposes such as criticism or review, provided that they relate to a work or other subject-matter which has already been lawfully made available to the public, that, unless this turns out to be impossible, the source, including the author's name, is indicated, and that their use is in accordance with fair practice, and to the extent required by the specific purpose. ${ }^{30}$

Aplin and Bently also acknowledge that the practice of EU Member States has not been to treat Article 10(1) as obligatory, with Sweden being one of the very few, and perhaps the only, country that has enacted domestic legislation that fully implements Article 10(1)'s requirements. ${ }^{31}$ They contend, however, that the EU's seemingly

Under the Three-Step Test?, 8 Rich. J. GLOB. L. \& Bus. 287, 290 (2009); Kur \& Ruse-Khan, Enough Is Enough, Max Planck Inst., supra note 2, at 18.

24. Kur \& Ruse-Khan, Enough Is Enough, Max Planck Inst., supra note 2, at 18, 38-39.

25. Id. at 18 (distinguishing optional limitations such as teaching or news reporting, which they characterize as relying only on "public interests").

26. See Mihály Ficsor, The LAW OF COPyright AND the InTERnet 9.09 (2002); Jørgen BlomQVist, Primer on International COPYRight AND Related Rights 159-60 (2014). See also

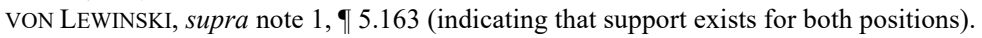

27. For example, Berne, art. 19 states: "The provisions of this Convention shall not preclude the making of a claim to the benefit of any greater protection which may be granted by legislation in a country of the Union." Similarly, Berne art. 20 provides that "[t]he Governments of the countries of the Union reserve the right to enter into special agreements among themselves, in so far as such agreements grant to authors more extensive rights than those granted by the Convention."

28. FICSOR, 2003 WIPO GUIDE, supra note 17, $₫ \mathrm{BC}-10.3$. Ficsor emphasizes that Article 10(1) is not mandatory, but only in principle. As a practical matter, the ability to quote is "indispensable" as it "follows from a basic human freedom - the freedom of free speech and criticism." Id. ๆ BC-10.4.

29. Id. at 130 n.57.

30. Directive 2001/29 of the European Parliament and of the Council of 22 May 2001 on the Harmonization of Certain Aspects of Copyright and Related Rights in the Information Society, art. 5(3)(d), 2001 O.J. (L 167) [hereinafter InfoSoc Directive] (emphasis added).

31. See Lionel Bently \& Tanya Aplin, Whatever Became of Global, Mandatory, Fair Use? A Case Study in Dysfunctional Pluralism, in Is InTELlectual Property PluRalism Functional? 8, 16 (Susy Frankel ed., 2019). For a review of European implementation of Article 10(1), see Martin Senftleben, Bridging the Differences Between Copyright's Legal Traditions-The Emerging EC Fair Use Doctrine, 57 J. COPYRIGHT SOC'Y U.S.A. 521 (2010). 
optional implementation of a quotation exception in the InfoSoc Directive is not necessarily in conflict with Article 10(1)'s requirement, as the Directive covers both Berne and non-Berne works: "The form of Article 5 is optional because it encompasses both an option and a duty: a duty to recognize a right of quotation from Berne works, but an option to recognize (or not) such a right in respect of neighboring rights." 32

In any event, while the scholarship is somewhat divided, the weight of authority seems to favor the interpretation that Article 10(1) is mandatory. ${ }^{33}$ Even amongst the commentators who agree that the quotation right is obligatory, however, there remains some disagreement about the right's implementation. Professors Goldstein and Hugenholtz, for example, argue that "[a]lthough Article 10(1) is mandatory rather than permissive, national legislatures presumably are free to prescribe the conditions on which quotation is permitted," and thus see no conflict in principle or practice with the InfoSoc Directive. ${ }^{34}$ For purposes of this Comment, we will grant the premise that Article 10(1) is mandatory, and will therefore consider its application to the new EU press publishers' right.

\section{B. Policy Underlying Berne Maxima And Its Preclusive Effect}

A concern to maintain the free international flow of basic elements of information appears to animate and unite the Berne maxima. These provisions offer the Berne Convention's strongest expression of solicitude for the broader public interest, notwithstanding the Convention's overall goal to protect the rights of authors. The Convention cannot prevent a member state from locally privatizing information its own authors generate - that is the consequence of Article 5(3) - but it can require that member states preserve the freedom of these excluded elements when the works that contain them traverse borders. Thus, if national legislation purports to grant protection to Berne Union authors in such cases, this must be contrary to the Convention.

Nor would Berne Article 19 change that conclusion. That provision declares that "[t]he provisions of this Convention shall not preclude the making of a claim to the benefit of any greater protection which may be granted by legislation in a country of the Union." It addresses protection for works of authorship, and therefore still comes within the general Berne framework. Under Article 5(1), authors enjoy rights "in respect of works for which they are protected under this Convention ...." Works, or elements of works, omitted or excluded from Berne subject matter thus fall outside the ambit of Article 19, and Union authors therefore have no treaty entitlement to protection for such subject matter. But the concept of Berne maxima goes farther, in that it would deny member states the option of according foreign Union authors copyright protection to certain subject matter (including the news of the day). By the same token, while Article 19 clearly extends to rights in protected subject matter that are not specified among conventional mandatory minimum rights, it should be

\footnotetext{
32. Bently \& Aplin, supra note 31, at 26.

33. See RICKETSON \& GINSBURG, supra note 1, \ 13.38.

34. GOLDSTEIN \& HUGENHOLTZ, supra note $1, \S 11.4 .1$, at 392.
} 
understood as entitling Union authors to claim "greater protection" in member states so long as their domestic law is not inconsistent with Berne norms. Member states may supplement Berne minimum rights, but may not undermine the policies underlying the principle of maximum protection. Whether as a matter of national treatment under Article 5(1), or of claim to greater rights under Article 19 (which, in this respect, reinforces the rule of national treatment to make clear that the rule extends beyond Conventional minima), the effect is the same: If domestic protection is "greater" because, for example, the member state does not provide for quotation rights, that state may not insulate foreign Berne works from acts coming within the scope of Article 10(1) because the member state would thus be rendering impermissible that which Berne declares "shall be permissible."

This reading of Article 19 can draw on support from Berne Article 20. This provision permits Berne Union members to enter into "special agreements among themselves, in so far as such agreements grant to authors more extensive rights than those granted by the Convention, or contain other provisions not contrary to this Convention." If those agreements exceed Berne maxima, then they contravene Article 20. One might infer a similar limitation in Article 19. Admittedly, one might instead contend, by way of negative inference, that the absence of a similar proviso in Article 19 suggests that Union authors may claim greater protection in a member state even if that state's domestic protection contravenes Berne. Such a rhetorically permissible reading, however, seems inconsistent with the overall structure and goals of Berne.

On the other hand, the "special agreements" Article 20 references concern authors' rights; they are copyright agreements. If Berne, TRIPS, and the WCT prohibit copyright coverage of ideas and facts, does it follow that member states may not protect those elements by other means, such as a sui generis neighboring right (in effect, removing the malodor by applying any other name to the same stinkweed), or by resort to another international norm, such as the Paris Convention's Article 10bis guarantee of protection against unfair competition? $?^{35}$ Can one derive a Berne/TRIPS/WCT-preclusive effect from those exclusions, or does the path remain open to member states to pursue protection by other means? DSM Directive Article 15 casts those questions into sharp relief, as we will see in the next Part.

\section{BERNE/TRIPS/WCT MAXIMA APPLIED: THE CASE OF THE DSM DIRECTIVE ARTICLE 15 PRESS PUBLISHERS' RIGHT}

First, an overview of the provision and its rationale, as set out in the accompanying Recitals. DSM Directive Article 15 provides, in relevant part:

\footnotetext{
35. Paris Convention Article 10bis provides:
}

(1)The countries of the Union are bound to assure to nationals of such countries effective protection against unfair competition.

(2)Any act of competition contrary to honest practices in industrial or commercial matters constitutes an act of unfair competition.

Paris Convention for the Protection of Industrial Property, Mar. 20, 1883, as amended Sept. 28, 1979, 21 U.S.T. 1583, 828 U.N.T.S. 305 [hereinafter Paris Convention]. 


\section{Protection of press publications concerning online uses}

1. Member States shall provide publishers of press publications established in a Member State with the rights provided for in Article 2 and Article 3(2) of Directive 2001/29/EC [reproduction and communication to the public] for the online use of their press publications by information society service providers.

$\cdots$

The rights provided for in the first subparagraph [of Article 15(1)] shall not apply in respect of the use of individual words or very short extracts of a press publication.

DSM Directive Article 2(4) defines "press publications" as:

a collection composed mainly of literary works of a journalistic nature, but which can also include other works or other subject matter, and which:

(a) constitutes an individual item within a periodical or regularly updated publication under a single title, such as a newspaper or a general or special interest magazine;

(b) has the purpose of providing the general public with information related to news or other topics; and

(c) is published in any media under the initiative, editorial responsibility and control of a service provider.

Periodicals that are published for scientific or academic purposes, such as scientific journals, are not press publications for the purposes of this Directive[.]

\section{A. Why Create a Press Publishers' Right?}

The EU Commission perceived that third-party online services' practices of news aggregation and other copying from the websites of newspapers and periodicals threatened those publications' continued existence. ${ }^{36}$ The Commission therefore provided a two-year ${ }^{37}$ neighboring right ${ }^{38}$ of the "the same scope as the rights of reproduction and making available to the public provided for in [the Information Society] Directive" and subject to "the same provisions on exceptions and limitations as those applicable to the rights provided for in [that] Directive, including the exception in the case of quotations for purposes such as criticism or review provided for in Article 5(3)(d) of that Directive." ${ }^{\prime 39}$ The objective is clear: to insulate press publishers from online services' predatory practices, and to require remuneration for

36. See DSM Directive, recital 54 ("Publishers of press publications are facing problems in licensing the online use of their publications to the providers of those kinds of services, making it more difficult for them to recoup their investments. In the absence of recognition of publishers of press publications as rightholders, the licensing and enforcement of rights in press publications regarding online uses by information society service providers in the digital environment are often complex and inefficient.").

37. Id. art. 15(4).

38. Id. recital 55 (referring to "rights related to copyright").

39. Id. recital 57 . 
the services' copying and communication to the public. ${ }^{40}$ But DSM Directive Article 15 's subject matter coverage is unclear. ${ }^{41}$ On the one hand, Recital 57 states: "The rights granted to publishers of press publications should not ... extend to mere facts reported in press publications." Recital 58 reinforces that exclusion. While extending the neighboring right to "parts of press publications," it cautions:

Such uses of parts of press publications have also gained economic relevance. At the same time, the use of individual words or very short extracts of press publications by information society service providers may not undermine the investments made by publishers of press publications in the production of content. Therefore, it is appropriate to provide that the use of individual words or very short extracts of press publications should not fall within the scope of the rights provided for in this Directive. Taking into account the massive aggregation and use of press publications by information society service providers, it is important that the exclusion of very short extracts be interpreted in such a way as not to affect the effectiveness of the rights provided for in this Directive. $^{42}$

The emphasized phrase suggests that the meaning of "very short extracts" may depend on the significance of the economic impact of their appropriation. In some instances, "the use of individual words or very short extracts of press publications by information society service providers may [might] not undermine the investments made by publishers of press publications in the production of content," but in other cases, service providers' "massive aggregation" of small amounts of content could cumulatively cause economic harm. An effective remedy therefore might need to apply granularly. But would such relief run afoul of Berne's subject-matter limitations?

\section{B. Does DSM Directive Article 15 Bestow Copyright Protection on BERNE-EXCluded SUbJECT MATTER?}

To the extent DSM Directive Article 15 provides extra-national copyright protection to the "news of the day" or "mere items of press information," it would violate Berne Article 2(8). ${ }^{43}$ Whether the rights conferred qualify as copyright"[t]he protection of [the Berne] Convention" 44 - or are more accurately characterized as a sui generis system of protection, is discussed in the following Part. Here, the question is whether "press publications" include the subject matter expressly excluded from protection under Berne Article 2(8).

To begin, it is necessary to determine the scope of Article 2(8)'s exclusions. What qualifies as "news of the day" or "items of press information"? The Berne provision excluding the news of the day and items of press information from protection was

40. Article 15(5) assumes that publishers will be paid by the services, because it provides for revenue-sharing with authors. Id. art. 15(5).

41. For a fuller analysis, see Elżbieta Czarny-Drożdżejk, The Subject-Matter of Press Publishers' Related Rights Under Directive 2019/790 on Copyright and Related Rights in the Digital Single Market, 51 INT’L REV. INTELL. PROP. \& COMPETITION L. [IIC] 624 (2020).

42. DSM Directive, recital 58 (emphasis added).

43. Berne, art. 2(8).

44. Id. 
moved from Article 9 to Article 2 during the 1967 Stockholm Conference revisions. ${ }^{45}$ As the Records of the Conference indicate, "[t]he precise meaning of the provision is far from clear." 46 The question of whether the provision could be improved or clarified was first raised by the Permanent Committee at its 1958 session in Geneva, and subsequently discussed by the Study Group in its 1963 Report. ${ }^{47}$ In its report, the Study Group ultimately adopted the following understanding of the provision:

The correct meaning of this provision is that it excludes from protection articles containing news of the day or miscellaneous information, provided that such articles have the character of mere items of news, since news of this kind does not fulfill the conditions required for the admission to the category of literary or artistic works. ${ }^{48}$

Thus, the role of the provision was merely "to recall the general principle whereby the title to protection of articles of this kind, as in the case of other intellectual works, presupposes the quality of literary or artistic works within the meaning of the Convention. ${ }^{449}$ Note that the Study Group perceived the exclusion to apply to entire articles, and not merely to the information they contained. It appears that the Study Group assumed that the articles would be so devoid of authorship as to fail to qualify as a "literary or artistic work." As such, the Study Group considered the "news of the day" exclusion to be a "superfluous element," 50 but retained the provision nonetheless. Moreover, though there had been some discussion of modifying the provision to improve clarity, the Study Group concluded that no modification was necessary, as "it would be sufficient to discuss the question of interpretation in the documents of the Conference." ${ }^{51}$ That position was reaffirmed in the Study Group's 1964 Report. $^{52}$

The report of the Main Committee on the Programme of the Conference reiterates this view, concluding that "the provision only seeks to establish that the Convention does not protect mere items concerning the news of the day or miscellaneous facts (and, a fortiori, the news or the facts themselves)." ${ }^{53}$ The provision was not intended, however, to exclude "articles" or "other journalistic works reporting the news ... if they can be considered as works within the meaning of the Convention." 54 On this point, the Committee believed, it could "hardly be claimed that there [was] any obvious need to clarify the text of the Convention." 55 Thus, Article 2(8) appears to function less as a provision of exclusion so much as a reiteration that recitations of facts that do not themselves qualify as intellectual creations, and therefore are not literary or artistic works, are not included.

45. WIPO, STOCKHOLM, supra note 22 , at $88-89$.

46. Id. at 115 .

47. $I d$.

48. Id.

49. Id.

50. Id.

51. Id.

52. Id.

53. Id. at 116 .

54. Id.

55. Id. 
The commentary on Article 2(8) is in accord. The 1978 Guide to the Berne Convention interprets the provision to exclude not only news and facts, but also "the simple telling of them, since matters of this kind lack the necessary conditions to be considered as falling into the category of literary and artistic works." ${ }^{.56}$ Claude Masouyé, the 1978 WIPO Guide's author, viewed the provision as merely confirming "the general principle that for a work to be protected, it must contain a sufficient element of intellectual creation." 57 Thus, while stories "related with a measure of originality" are protected under Article 2(1), "simple account[s], arid and impersonal, of news and miscellaneous facts" are not. ${ }^{58}$

Given the above understanding, DSM Directive Article 15 would violate Berne Article 2(8) if its protection of press publications extends either to facts themselves or to mere recounting of facts that lack sufficient original expression. As defined in the DSM Directive, press publications are certain collections "mainly composed of literary works of a journalistic nature, but which may include other works or other subject matter." 59 While "literary works," and "works" generally, are properly the subject of copyright protection under Berne,${ }^{60}$ the possibility of inclusion of "other subject matter" within the scope of protection raises a potential conflict with Berne Article 2(8). Specifically, would the "news of the day" and "items of press information" be included within this "other subject matter" and consequently protected? Recital 56 of the DSM Directive provides some elaboration on the scope of protection. In particular, Recital 56 clarifies that "press publications contain mostly literary works, but increasingly include other types of works and other subject matter, in particular photographs and videos." 61 Though presumably not exhaustive, the illustrative examples of photographs and videos as other types of work and subject matter suggest the Directive is not intended to cover the otherwise unprotectable "news of the day" or "items of press information," since photographs and videos generally qualify as artistic works. Recital 57 is more explicit-the rights granted to publishers of press publications "should also not extend to mere facts reported in press publications." 62 Still, as explained above, Berne Article 2(8) appears to extend slightly beyond the facts themselves and also excludes sterile accounts of facts, regardless of length. Thus, while DSM Directive Article 15 may not protect facts or "individual words or very short extracts of a press publication," 63 to the extent it protects press publications that include factual accounts too lacking in originality to support a copyright, ${ }^{64}$ the Directive may be covering subject matter

56. Claude Masouyé, WiPO Guide To the Berne Convention for the Protection of LITERARY AND ARTISTIC WORKS (PARIS ACT, 1971) 『 2.27 (1978).

57. Id.

58. Id. The 2003 Guide, perhaps deferring to the belief of the 1963 Study Group, merely quotes the Conference records provided above. See FICSOR, 2003 WIPO GUIDE, supra note 17, 9 BC-2.71.

59. DSM Directive, art. 2(4) (emphasis added).

60. See Berne, art. 2(1).

61. DSM Directive, recital 56.

62. Id. recital 57.

63. Id. art. 15(1).

64. Including, potentially, algorithmically-generated news reports lacking sufficient human authorship to qualify as "works" under Berne. 
excluded under Berne Article 2(8). Moreover, as discussed above, the potential for coverage of economically valuable "very short extracts" might create tension with Berne Article 2(8).

\section{May the EU Protect Berne-Adjacent Subject Matter Through SuI GENERIS SYSTEMS?}

Berne Article 2(8) excludes certain subject matter from copyright protection, but it generally does not prevent Union members from protecting that subject matter under different regimes, including sui generis forms of protection. ${ }^{65}$ An initial question then is whether DSM Directive Article 15 vests publishers with copyrights in press publications or instead establishes a sui generis system. Though DSM Directive Article 15(1) nominally provides the same copyright protections as conferred in Articles 2 and 3 of the InfoSoc Directive, it limits those rights in important ways not consistent with other copyright protection. Perhaps most importantly, the primary beneficiary and holder of the right is not necessarily the author(s), but the publisher. ${ }^{66}$ Second, the term of protection is limited to just two years beginning with publication (in contrast to Berne's minimum fifty years post mortem auctoris). ${ }^{67}$ Additionally, the scope of the Article 15 right is limited specifically to "online use[s]" by information service providers and does not apply "to acts of hyperlinking." 68 Recital 55 also makes clear that the rights granted are not copyrights per se, but "rights related to copyright." Finally, the granting of rights is not expressly predicated on the presence of original expression, but rather the "organisational and financial contribution of publishers in producing press publications." ${ }^{69}$ Given these significant differences from the traditional copyright regime, there is a strong argument that the rights granted in press publications are not just copyright by another name, but instead are genuinely sui generis.

One then must ask whether the protection of this Berne-adjacent subject matter through a sui generis regime is permissible. As Annette Kur and Henning Grosse Ruse-Khan observe, the ability to protect Berne-excluded subject matter through

65. See discussion infra Part II.C.

66. DSM Directive, art. 15(1). However, note that DSM Directive Article 15(5) requires member states to "provide that authors of works incorporated in a press publication receive an appropriate share of the revenues that press publishers receive for the se of their press publications by information society service providers."

67. $I d$. art. $15(4)$.

68. Id. art. 15(1). The extent to which unauthorized hyperlinking constitutes a copyright-infringing "communication to the public" is uncertain, given the evolving case law of the Court of Justice of the European Union (CJEU). See, e.g., Jane C. Ginsburg \& Alain Strowel, Liability for Hyperlinking, in Research Handbook on Intellectual Property and Digital Technologies (Tanya Aplin ed., 2020); Jane C. Ginsburg \& Luke Ali Budiardjo, Liability for Providing Hyperlinks To CopyrightInfringing Content: International and Comparative Law Perspectives, 41 COLUM. J.L. \& ARTS 153 (2018); Alain Strowel \& Vicky Hanley, Secondary Liability for Copyright Infringement with Regard To Hyperlinks, in PEER-TO-PEER FILE SHARING AND SECONDARY LiABILITY IN COPYRIGHT LAW 71 (Alain Strowel ed., 2009); Matthias Leistner, Closing the Book on Hyperlinks: Brief Outline of the CJEU's Case Law and Proposal for European Legislative Reform, 39 EUR. INTELL. PROP. REV. [EIPR] 327 (2017).

69. DSM Directive, recital 55. 
different means is problematic. ${ }^{70}$ Nonetheless, both the Records of the Stockholm Conference and the commentary on the 1971 Paris text of the Berne Convention agree that such protection is permissible. As described in the Conference Records, one of the utilities of Berne Article 2(8), despite its otherwise superfluous nature, was to "permit the conclusion that if the articles concerned are protected by other legal provisions - for example, by legislation against unfair competition-such protection is outside the field of the Convention."71 Similarly, the provision helped to fix "the line of demarcation between copyright and other means of protection."72 Thus, the possibility of other means of protection was expressly contemplated and was accompanied by no signs of disapproval.

Commentary on Berne Article 2(8) also endorses the view that sui generis protection is permissible. Paul Goldstein and Bernt Hugenholtz state that "[1]ike ideas, news of the day and data compilations may be protected outside copyright under unfair competition law, neighboring rights, or sui generis regimes."73 Similarly, in the 2003 WIPO Guide, Ficsor notes that the subject matter of Article 2(8) can be protected "on the basis of some legal institutions other than copyrightsuch as a sui generis system for the protection of databases and their contents, or unfair competition ...."74 Other commentators agree. ${ }^{75}$ Indeed, although they acknowledge that the results may be troublesome, Kur and Ruse-Khan emphasize that the relevance of TRIPS Article 1(1) and Berne Article 2(8) "is limited to mandatory exclusion of subject matter from copyright, whereas it does not appear as a tenable position to argue that it also applies if information or data are under a sui generis regime deliberately established for the purpose of granting such protection." 76

The European Union's adoption of the Database Directive occasioned concrete application of the principle that a sui generis right might supply protection withheld by the Berne Convention. ${ }^{77}$ Similarly to Article 15 of the DSM Directive, the Database Directive provides sui generis protection with respect to the substantial investment in the compilation of otherwise unprotectable data. While the Database

\footnotetext{
70. Kur \& Ruse-Khan, Enough Is Enough, Max Planck Inst., supra note 2, at 44.

71. WIPO, STOCKHOLM, supra note 22, at 115.

72. Id.

73. GOLDSTEIN \& HUGENHOLTZ, supra note $1, \S 6.1 .3$, at 220 .

74. FICSOR, 2003 WIPO GUIDE, supra note 17, $₫$ BC-2.73.

75. See, e.g., Laurence R. Helfer, Adjudicating Copyright Claims Under the TRIPS Agreement: The Case for a European Human Rights Analogy, 39 HARV. INT'L L.J. 357, 358 n.41 (1998) (“Although the treaty "shall not apply to news of the day or to miscellaneous facts having the character of mere items of press information,' and provides that '[i]t shall be permissible to make quotations from a work' under certain conditions, these two isolated provisions do not prohibit states from imposing higher levels of copyright protection in other areas, nor even from protecting news, miscellaneous facts, and quotations under other intellectual property doctrines.”); RICKETSON \& GINSBURG, supra note 1, \ 8.90.

76. Kur \& Ruse-Khan, Enough Is Enough, Max Planck Inst., supra note 2, at 44 (first emphasis added).

77. Directive 96/9/EC of the European Parliament and the Council of 11 March 1996 on the Legal Protection of Databases, 1996 O.J. (L 77) [hereinafter Database Directive].
} 
Directive has incurred both practical and theoretical objections, ${ }^{78}$ these criticisms have not evoked an underlying incompatibility with Berne Article 2(8). Similarly, while a draft treaty proposing international protection for databases was not adopted at the Diplomatic Conference on Certain Copyright and Neighboring Rights Questions in 1996 (or anytime thereafter), there is no record of objections premised on the exclusion of such subject matter from copyright. ${ }^{79}$ Rather, the debate has centered around which form of legal protection-a sui generis intellectual property protection or a misappropriation right sounding in unfair competition-was best suited to the task of protecting the investment in compiling databases. Advocates of more expansive and definite protection preferred a sui generis right with more precise details, well-defined term of protection, and greater facility for licensing. ${ }^{80}$ Skeptics of the economic benefits or necessity of database protection favored the more limited protection of misappropriation claims. ${ }^{81}$ In any event, the ability of Berne members to establish other forms of protection, including sui generis intellectual property rights, seems to have gone unquestioned.

\section{EVEN WERE A SUI GENERIS RIGHT IN BERNE-EXCLUDED SUBJECT MATTER PERMISSIBLE, MUST EXCEPTIONS TO THAT RIGHT BE INTERPRETED CO-EXTENSIVELY WITH THE BERNE ARTICLE 10(1) QUOTATION RIGHT?}

In the absence of a full examination of what constitutes a "quotation" under Berne Article 10(1), ${ }^{82}$ one may nonetheless question whether the press publishers' right is compatible with Berne Article 10(1). DSM Directive Article 15(3) directs that the exceptions set out in the 2001 InfoSoc Directive "shall apply mutatis mutandis in respect of the rights provided for in paragraph 1 of this Article." 83 The latter instrument's incorporation of an optional quotation privilege in terms nearly identical to Berne Article 10(1), ${ }^{84}$ suggests that one may avoid discrepancies between the two

78. See, e.g., Jörg Reinbothe, The Legal Protection of Non-Creative Databases, Presentation at Protection of Databases Workshop, WIPO International Conference on Electronic Commerce and Intellectual Property (Sept. 14-16, 1999), https://perma.cc/9RHK-YYPM; Herman Cohen Jehoram, Two Fashionable Mistakes, 22 Eur. InTELL. Prop. Rev. [E.I.P.R.] 103 (2000); J. L. Gaster, The EC Sui Generis Right Revisited After Two Years: A Review of the Practice of Database Protection in the 15 EU Member States, 5 TOlley's CommC'NS L. 87-98 (2000); Jane C. Ginsburg, Copyright, Common Law, and Sui Generis Protection of Databases in the United States and Abroad, 66 U. CIN. L. REV. 151 (1997).

79. See 1 WIPO, ReCORDS OF THE Diplomatic CONFERENCE ON CERTAIN COPYRIGHT AND NEIGHBORING RIGHTS QUESTIONS OF GENEVA 1996 (1999).

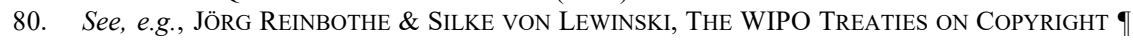
13.0.19(2015)

81. Id.

82. See APLIN \& BENTLY, supra note 2.

83. DSM Directive, art. 15(3). See also id. recital 57.

84. InfoSoc Directive Article 5 provides in relevant part:

3. Member States may provide for exceptions or limitations to the rights provided for in Articles 2 and 3 in the following cases: 
instruments by interpreting DSM Directive Article 15 coextensively with InfoSoc Directive Article 5(d), which in turn should track Berne Article 10(1). In that event, the copyright-adjacent nature of DSM Directive Article 15, while potentially problematic with respect to covered subject matter, will not immunize the press publishers' right from third parties' quotation rights.

This conclusion comes with two caveats: First, the quotation right in Berne, according to most commentators, is mandatory; member states must allow quotations (within the contours of the right). By contrast, the InfoSoc Directive leaves Berne Article 5(3)'s list of permitted exceptions and limitations up to national adoption (or not). On the other hand, DSM Directive Article 17(7) makes the quotation exception, among others, mandatory with respect to content posted by users to Online Content Sharing Service Providers. ${ }^{85}$ While DSM Directive Article 17, on the liability of Online Content Sharing Service Providers for infringing content posed by their users, addresses a different problem from the one that occasioned DSM Directive Article 15 , there may be some overlap between the entities that are "online content-sharing service providers" under DSM Directive Article 17, and the "information society service providers" subject to the press publishers' right. Arguably, the EU may be closely creeping toward substantive equivalence with the Berne norm with respect to its mandatory character. ${ }^{86}$

Second, even assuming third parties will enjoy quotation rights in press publications, the scope of the quotation exception may differ between InfoSoc Directive Article 5(3)(d) and DSM Directive Article 15(3). The same words may mean different things in different contexts, and the requirement that the quotation be "in accordance with fair practice" may impose different constraints on the exercise

(d) quotations for purposes such as criticism or review, provided that they relate to a work or other subject-matter which has already been lawfully made available to the public, that, unless this turns out to be impossible, the source, including the author's name, is indicated, and that their use is in accordance with fair practice, and to the extent required by the specific purpose[.]

Berne Article 10(1) states:

It shall be permissible to make quotations from a work which has already been lawfully made available to the public, provided that their making is compatible with fair practice, and their extent does not exceed that justified by the purpose, including quotations from newspaper articles and periodicals in the form of press summaries.

85. DSM Directive Article 17(7) states in relevant part:

Member States shall ensure that users in each Member State are able to rely on any of the following existing exceptions or limitations when uploading and making available content generated by users on online content-sharing services:

(a) quotation .... .

86. See Case C-476/17 Pelham GmbH v. Hütter ECLI:EU:C:2018:1002, ๆ 77 (Dec, 12, 2018) (Opinion of Advocate General Szpunar) (suggesting the need to interpret EU copyright exceptions in light of mandatory human rights: "[T]he exclusive rights provided for unconditionally and compulsorily for the Member States in Articles 2 to 4 of Directive 2001/2009 are subject only to the exceptions and limitations listed exhaustively in Article 5(1) to (3) of that directive. . . It should be noted, however, that that degree of latitude is also limited, since some of those exceptions reflect the balance struck by the EU legislature between copyright and various fundamental rights, in particular the freedom of expression. Failing to provide for certain exceptions in domestic law could therefore be incompatible with the Charter.'). 
of the quotation right. Given that the practice of news aggregation spurred DSM Directive Article 15's enactment, the size and amount of the "quotations," and their economic impact may bear more heavily on the assessment of incompatibility with fair practice for press publications than courts might tolerate for works of authorship. Thus, interpretation of the two instruments may not be fully coextensive: The principles may be the same, but their application may not yield identical results. (On the other hand, the same might be said of the assessment of "fair practice" across different kinds of works of authorship, or regarding different purposes for the quotations.)

DSM Directive Article 15's adoption of the InfoSoc Directive's exceptions avoids a confrontation between Berne norms and an unbounded sui generis right over subject matter that includes works of authorship as well as Berne-excluded content. Recall that DSM Directive Article 2(4) defines press publications to cover "an individual item within a periodical"; that item generally will be a whole article or a substantial extract. (Recital 58 generally excludes "very short extracts," though the meaning of the term may vary with economic impact.) Acknowledging that a neighboring rights regime over Berne-excluded subject matter may coexist with copyright,${ }^{87}$ one may still inquire whether Berne maxima should exert a preclusive effect when the subject matter of the sui generis right includes works of authorship. If, for example, DSM Directive Article 15 covered both copyrightable and noncopyrightable content, but did not also incorporate copyright exceptions, so that a quotation exception would not limit the scope of the press publishers' right, then publishers could invoke the sui generis right to prevent quotations from the same copyrightable content to which their rights under copyright must yield ${ }^{88}$ The argument for a Berne-preclusive effect seems strongest when the sui generis right covers both copyrightable and non-copyrightable content. It should not be permissible to end-run the Berne quotation right by resort to sui generis protection against copying the same subject matter.

However, Chapter III, "Sui Generis Right," of the 1996 Database Directive may belie that proposition. As we have seen, the Database Directive covers both original and non-original databases, and provides a sui generis right against extraction and reutilization of substantial parts (whether or not copyright-infringing) of databases that are the fruit of substantial investment. While Chapter II, "Copyright," of the Directive permits member states to provide for copyright exceptions "traditionally authorized under national law," ${ }^{89}$ Chapter III sets out three specific exceptions and limitations (which do not include a quotation provision), without Chapter II's openended catch-all. ${ }^{90}$ Chapter III's restriction of the extraction right to "insubstantial

87. See discussion supra Part II.B.

88. A similar observation has been made regarding the overlap of copyright/sui generis rights in the EU Database Directive (discussed more fully infra). See Mark Powell, The European Union's Database Directive: An International Antidote To the Side Effects of Feist?, 20 FORDHAM INT'L L.J. 1215,1244 (1997) ("[A]uthors of copyrightable works contained in a database may henceforth elect to invoke their sui generis right, rather than their copyright, in order to side-step the fair dealing exception.")

89. Database Directive, art. 6(2)(d).

90. Id. art. 9 . 
parts" of the database will place some quotations outside the ambit of the database holder's exclusivity. ${ }^{91}$ But to the extent that a copyright-permissible "quotation" may be qualitatively or quantitatively substantial, ${ }^{92}$ Chapter III of the Database Directive would appear to grant the right holder a remedy, where Chapter II would allow an exception. If non-copyright material entirely comprises the "quotation," then once one has admitted the premise that Berne member states may establish sui generis rights in copyright-excluded content, perhaps copyright limitations need not constrain the scope of rights in that subject matter (although it seems problematic that sub-copyrightable content would receive more protection than original works of authorship). But if the quotation comprehends a substantial extract of copyrightable expression, then Chapters II and III appear in tension. ${ }^{93}$

\section{CONCLUSION}

Within the universe of multilateral copyright obligations, the Berne maxima, buttressed by the TRIPS and WCT exclusions of protection for ideas, methods, and processes, should promote the free cross-border availability of facts and ideas, as well as of exercise of the quotation right. Individual Berne countries of origin may protect excluded subject matter in their own works of authorship, but not in foreign Berne works. Conversely, those countries must apply the quotation right to foreign Berne works, but need not to their own. Nonetheless, there exist at least two challenges to this equilibrium. The first, as we have seen, concerns the potential for Berne members to protect excluded subject matter, or to avoid the quotation right, by resort to sui generis regimes. The second concerns the EU principle of nondiscrimination: Berne may limit protection in excess of its maxima to the country of origin, but EU norms require Member States to accord full national treatment, thus granting to works by other EU nationals the same scope of protection as the EU country of origin provides its own authors. ${ }^{94}$ This cornerstone of EU law potentially places EU member states in conflict with their international obligations: On the one

91. Id. art. 8

92. As Aplin and Bently argue it should be. See APLIN \& BENTLY, supra note 2, at 6.

93. For discussions of this tension, see Matthias Leistner, Big Data and the EU Database Directive 96/9/EC: Current Law and Potential for Reform 13-18 (Sept. 7, 2018), https://perma.cc/NRL7-AJXV ("[T] he narrow exceptions to the sui generis right should at least be aligned and dynamically linked with the exceptions to copyright law under the Information Society Directive. It is therefore of considerable practical interest also to enable, and oblige, Member States to extend, mutatis mutandis, the exemptions and limitations applying to works protected under copyright, to sui generis protection of non-original databases. The obligation should be phrased so as to establish a dynamic link between both fields, to the effect that limitations set out in new copyright legislation would automatically also become applicable, under suitable terms and circumstances, to the sui generis right."). For comparison of the scope of exceptions to the database right relative to rights under copyright, see Annette Kur, Reto M. Hilty, Christophe Geiger \& Matthias Leistner, First Evaluation of Directive 96/9/EC on the Legal Protection of Databases-Comment by the Max Planck Institute for Intellectual Property, Competition and Tax Law, Munich, 37 INT'L REV. INTELL. PROP. \& COMPETITION L. [IIC] 551, 556 (2006).

94. See, e.g., Joined Cases C-92/92 and C-326/92, Collins v. Imtrat Handelsgesellschaft mbH \& Patricia Im- und Export Verwaltungsgesellschaft mbH, Kraul v. EMI Electrola GmbH, 1993 E.C.R. I5145; Case C-360/00, Land Hessen v. G. Ricordi \& Co. Bühnen- und Musikverlag GmbH, 2002 E.C.R. I-5089. 
hand, they may not - by copyright — protect Berne-excluded subject matter in foreign works, including works by EU nationals; on the other hand, EU norms oblige member states to extend to other EU nationals the protections Berne would deny them. 